\title{
Relationship between Body Mass Index and Visceral Fat of Participants EXPO 2021 Universitas Teuku Umar
}

\author{
${ }^{1}$ Adelina Irmayani Lubis, ${ }^{2}$ Suci Eka Putri, ${ }^{3}$ Safrida, ${ }^{4}$ Hanif Muchdatul Ayunda, ${ }^{5}$ Arif Iskandar. \\ ${ }^{1}$ Universitas Teuku Umar, Indonesia, adelina.irmayani@utu.ac.id \\ ${ }^{2}$ Universitas Teuku Umar, Indonesia, suciekaputri@utu.ac.id \\ ${ }^{3}$ Universitas Teuku Umar, Indonesia, safridam.si@utu.ac.id \\ ${ }^{4}$ Universitas Teuku Umar, Indonesia, hanifmuchdatul@utu.ac.id \\ ${ }^{5}$ Universitas Teuku Umar, Indonesia, arifiskandar@utu.ac.id \\ Corresponding author : Adelina Irmayani Lubis, e-mail : adelina.irmayani@utu.ac.id
}

\begin{abstract}
Visceral fat levels contribute to obesity. Visceral fat is fat accumulation in fatty tissue around intra-abdominal organs or commonly referred to as central obesity. The higher the Body Mass Index, the percentage of fat mass and visceral fat will increase. Obesity can have an impact on insulin resistance, metabolic syndrome disorders and degenerative diseases. This study aims to determine the relationship between body mass index (BMI) and visceral fat. This study uses a cross-sectional design and descriptive-analytic, looking for the relationship between body mass index and visceral fat level. The result shows about $53,6 \%$ and $25 \%$ of overweight respondents with high and very high visceral fat levels. There is a relationship between body mass index and visceral fat level with p-value obtained is 0,00 (pvalue $<0,05)$. It means that there is a risk of obesity and metabolic syndrome disorders. Prevention efforts are needed by increasing physical activity, consumption of vegetables and fruit, and routine general checks up.
\end{abstract}

How to cite this article: Lubis .AI, Putri, S.E, Safrida, Ayunda, H.M, Iskandar A. (2021). The Relationship between Body Masss Index and Visceral Fat of Participants EXPO 2021 Universitas Teuku Umar. Journal of Nutrition Science, 2 (2), 15-19

\section{Introduction}

Visceral fat is fat accumulation in fatty tissue around intra-abdominal organs, commonly referred to as central obesity (Shuster et al., 2012). Obesity defines as excess or abnormal fat mass (Ellulu et al., 2014). Central obesity occurs because of high visceral fat (Low et al., 2009).

Body Mass Index (BMI) is a simple method to assess nutritional status related to visceral fat (Pradana, 2014). Categorization of nutritional status based on BMI, namely underweight, normal, overweight and obesity (Kemkes). The higher the BMI, the percentage of fat mass and visceral fat will increase (Fatimah et al., 2017). Visceral fat will also affect the abdominal circumference, so that the higher the percentage of visceral fat will increase the risk of experiencing central obesity (Fatimah et al., 2017 \&

\section{ARTICLE INFORMATION}

\author{
Submitted: $31 / 10 / 2021$ \\ Revised: 01/11/2021 \\ Accepted: 02/11/2021 \\ Publish Online: 06/11/2021
}

\section{Keywords: \\ Body Mass Index \\ Visceral Fat} contribute to visceral fat in white men and women also contribute to the prediction of total and abdominal obesity. Increased abdominal fat with high WC and BMI predicts visceral, subcutaneous fat. In overweight men and women, visceral fat accounts for about $83 \%$ of the increase in abdominal fat (Janssen et al., 2002).

Obesity impacts Insulin Resistance (IR) and increases metabolic disorders (Kurniawan et al., 2018). The proportion of obesity is increasing every year in Indonesia. Riskesdas 2018 data, the proportion of overweight increased from $11.5 \%$ in 2013 to $13.6 \%$ in 2018. The proportion of obesity increased from $14.8 \%$ in 2013 to $21.8 \%$ in 2018 . In contrast, the proportion of central obesity in 2018 of $31 \%$ was 
seen based on abdominal circumference as an indicator of central obesity (Riskesdas, 2018).

Visceral fat level contributes to obesity, namely central obesity, where there is an increase in body fat, resulting in insulin resistance as the basis for metabolic syndrome disorders (Susantini, 2021 \& Eloi et al., 2017). A metabolic syndrome is a group of risk factors that increase the likelihood of developing cardiovascular disease, stroke, and type 2 diabetes mellitus (Alberti et al., 2009).

Excess visceral fat deposits are associated with type 2 diabetes mellitus, hypertension, and atherogenesis (Pradana, 2014 \& Samuel, 2012). Another study states that Visceral Fat (VF) is the leading cause of cardiovascular disease, type 2 diabetes mellitus, breast cancer, etc. (Gadekar et al., 2020).

This study aims to determine the relationship between body mass index (BMI) and visceral fat. It is a contribution to knowing the risk of degenerative diseases.

\section{Method}

This study's population and subjects are all participants EXPO 2021 of the Universitas Teuku Umar, selected using a stratified random sampling method. This study was conducted from 16-18 February 2021 at Universitas Teuku Umar. This study uses a cross-sectional design because the measurement of the dependent variable and the independent variable of the study was carried out at the same time. This research is descriptive-analytic, looking for the relationship between body mass index and visceral fat level.

The dependent variable in this study is visceral fat level and the variable independent is Body Mass Index (BMI). Body height measurement in this study used a stature meter tool, while body weight measurement and body composition determination used Karada scan.

The data obtained were then analyzed using SPSS software. Univariate analysis was performed to identify body mass index and visceral fat level. Bivariate analysis using the chi-square test to determine the relationship between body mass index and the visceral fat level, with a significance value $(\mathrm{p}=0.05)$.

\section{Results}

The respondent characteristic of this study was shown in Table 1, which was about the frequency distribution category of body mass index and visceral fat level.

Table 1. Frequency Distribution Category of Body Mass Index

\begin{tabular}{lcc}
\hline Body Mass Index & Total & \% \\
\hline $\begin{array}{l}\text { Underweight } \\
\text { (below 18,5) }\end{array}$ & 10 & 11,1 \\
$\begin{array}{l}\text { Normal } \\
(18,5-25,0)\end{array}$ & 52 & 57,8 \\
$\begin{array}{l}\text { Overweight } \\
(\text { above 25,0) }\end{array}$ & 28 & 31,1 \\
TOTAL & 90 & 100,0 \\
\hline
\end{tabular}

Based on Table 1, show the nutritional status of respondents is known to be the highest, namely normal as much as $57,8 \%$ and the lowest with a thin nutritional status of $11,1 \%$. But there are about 31,1 $\%$ of respondents with overweight nutritional status.

Table 2. Frequency Distribution Category of Visceral Fat Level

\begin{tabular}{lcc}
\hline Visceral Fat Level & Total & \% \\
\hline Normal $(0,5-9,5)$ & 64 & 71,1 \\
High $(10-14,5)$ & 18 & 20,0 \\
Very High $(15-30)$ & 8 & 8,9 \\
TOTAL & 90 & 100,0 \\
\hline
\end{tabular}

Based on Table 2, the visceral fat level is known to be the highest, namely normal as much as $71,1 \%$. But there is about $20 \%$ and $8,9 \%$ of respondents with high and very high visceral fat levels.

Table 3. Chi-Square Test Result of Relationship between Body Mass Index and Visceral Fat Level

\begin{tabular}{|c|c|c|c|c|c|c|c|c|c|}
\hline \multirow{3}{*}{$\begin{array}{l}\text { Body Mass } \\
\text { Index }\end{array}$} & \multicolumn{6}{|c|}{ Visceral Fat Level } & \multirow{2}{*}{\multicolumn{2}{|c|}{ Total }} & \multirow{3}{*}{$\begin{array}{l}\text { P- } \\
\text { Val } \\
\text { ue }\end{array}$} \\
\hline & \multicolumn{2}{|c|}{ Normal } & \multicolumn{2}{|c|}{ High } & \multicolumn{2}{|c|}{$\begin{array}{l}\text { Very } \\
\text { High }\end{array}$} & & & \\
\hline & $\mathbf{n}$ & $\%$ & n & $\%$ & $\mathbf{n}$ & $\%$ & $\mathbf{n}$ & $\%$ & \\
\hline $\begin{array}{l}\text { Underweight } \\
\text { and Normal }\end{array}$ & 58 & 93,5 & 3 & 4,8 & 1 & 1,6 & 62 & 100 & 0,00 \\
\hline Overweight & 6 & 21,4 & 15 & 53,6 & 7 & 25,0 & 28 & 100 & \\
\hline
\end{tabular}

Based on Table 3, about $53,6 \%$ and $25 \%$ of respondents were overweight with high and very high visceral fat levels. Bivariate analysis results show that the $\mathrm{p}$-value obtained is $0,00(\mathrm{P}<0,05)$. It means 
that there is a relationship between body mass index and visceral fat level.

\section{Discussion}

Based on the study results, about $31.1 \%$ of respondents had a body mass index of overweight. BMI indicates a person's nutritional status, calculating the weight divided by the squared height. In Janssen et al. (2002) study, BMI and WC were associated with visceral fat. Health risks increase if the excess experience total, abdominal and visceral fat (Janssen et al., 2002). The same results were also shown in the research of Ayusari et al. (2019). Namely, people who have high BMI scores will have total fat mass and increased visceral fat mass (Ayusari et al., 2019).

BMI can also be obtained from the calculation of body fat mass. Visceral fat as a component of the body can also affect BMI (Arisman, 2011). Visceral fat is one of the components in the human body that can affect body weight (Arisman, 2011). The results of our study showed that about $20 \%$ and $8.9 \%$ of respondents had high and very high visceral fat. The visceral fat level contributes to the incidence of obesity, namely central obesity, where there is an increase in body fat, resulting in insulin resistance as the basis for metabolic syndrome disorders.

This study shows a relationship between BMI and visceral fat with a p-value of 0,00 ( $\mathrm{p}$-value $<0,05$ ). About $53.6 \%$ and $25 \%$ of respondents have an overweight BMI with high and very high visceral fat. The results of our study are the same as those of Susantini, 2012 which showed that there was a relationship between BMI and visceral fat (Janssen, 2002, Susantini, 2012, Wang, 2013). Another study also showed the same thing, namely a positive correlation between BMI and visceral fat level $(\mathrm{p}<0,05$, rho $=0,912)$. The results of this study indicate a positive relationship between BMI and visceral fat values, which means that the tendency to increase BMI is also accompanied by an increase in visceral fat level (Wei Ping, 2003 \& Pradana, 2014).

The higher the BMI, namely in the overweight and obese categories, the higher the body visceral fat. An overweight person has indicated that he will be at risk for obesity if his nutritional status is not improved. Obesity increases body fat components, one of which is visceral fat (Hall, 2015). BMI and WC contribute to predicting total and abdominal obesity (Janssen et al., 2002). BMI and WC as more accurate tools to assess visceral adiposity in young adults (Sommer, 2020).

Visceral fat is also called intraperitoneal fat. It surrounds the mesentery and omental fat mass. Metabolic obesity (visceral obesity with normal weight) is a fat level that is higher than the normal limit, even though a person's weight is within or below the standard height. The person is thin on the outside but fat on the inside (Gadekar, 2020). Not everyone who has a normal BMI means they are healthy, but they may have a lot of fat with very little muscle and still be at risk for cardiovascular disease (Yagnik, 2004).

Other studies have also found an increase in visceral fat due to a high-fat diet (Yasmeen, 2013). BMI and WC can be used as treatment targets to assess the fat compartment in reducing the risk of metabolic disorders and health risks in the young adult population (Pasanta, 2021). BMI and WC are also predictors of cardiovascular disease and type 2 diabetes mellitus (Janssen et al., 2002). Other studies say that visceral fat is a risk factor for liver steatosis. The risk of hepatic steatosis is higher in patients with higher visceral fat (Lee, et al, 2017).

Based on this description, it can be concluded that there are health problems that arise if visceral fat and obesity can increase the risk of degenerative diseases to death. So it is necessary to make efforts to increase physical activity, exercise, balanced food intake, and others. 


\section{Conclusion}

This study concludes that there is a relationship between Body Mass Index (BMI) and Visceral Fat with $\mathrm{p}<0.05$. It needs to be a concern because the higher the visceral fat it will contribute to obesity. It can be dangerous because it will have an impact on degenerative diseases. In this study, respondents did not explain the physical activity and food intake. Therefore, the researcher recommends that this study be carried out in the future. Prevention efforts can be done by increasing physical activity, exercise, balanced food intake, and healthy living behavior. It can be done with continuous efforts to implement the GERMAS program, significantly increasing consumption of fruits and vegetables, regular physical activity, and routine health checks.

\section{References}

A Shuster, M Patlas, MD, J H Pinthus, and $\mathrm{M}$ Mourtzakis. (2012). The clinical importance of visceral adiposity: a critical review of methods for visceral adipose tissue analysis. $\mathrm{Br} J$ Radiol, $\quad 85(1009), \quad 1-10 . \quad$ https://doi: $10.1259 / \mathrm{bjr} / 38447238$.

Alberti, K.G.M.M., Eckel, R.H., Grundy, S.M., Zimmet, P.Z., Cleeman, J.I., Donato, K.A., Fruchart, J.-C., James, W.P.T., Loria, C.M., \& Smith, S.C. (2009). Harmonizing the Metabolic Syndrome. Circulation 2009, 120, $1640-1645$.

Arisman. (2011). Obesitas, Diabetes mellitus \& Dislipidemia. Mahode AA, Astuti NZ, editor. Jakarta: EGC. p. 162-5.

Ayusari, A.A., Wiboworini, B., Damayanti, K.E., Rahayu, D., Widardo, Lanti, Y., Krisna, P.A., Thoriqurrohman, M., Faniya, A.H., \& Ummah, F.R. (2019). Correlation between Dietary Fat Consumption With Body Mass Index and Body Composition (A Preliminary Study in Community Based). Health Science Journal of Indonesia, 10 (2).

Ellulu, M., Abed, Y., Rahmat, A., Ranneh, Y., \& Ali, F. (2014). Epidemiology of Obesity in Developing Countries: Challenges and Prevention. Glob Epidemi Obes. 2014; 2:2. http://dx.doi.org/10.7243/2052-5966-2-2.

Eloi, J.C., Epifanio, M., de Goncalves, M.M., Pellicioli, A., Vieira, P.F., Dias, H.B., Bruscato, N., Soder, R.B., Santana, J.C.,
Mouzaki, M., et al. (2017). Quantification of Abdominal Fat in Obese and Healthy Adolescents Using 3 Tesla Magnetic Resonance Imaging and Free Software for Image Analysis. PLoS ONE 2017, 12, e0167625.

Fatimah,S.N., Akbar, I.B., Purba, A., Tarawan, V.M., Nugraha, G.I., Radhiyanti, P.T, \& Nurhayati, T. (2017). Hubungan Pengukuran Lemak Subutan dengan Indeks Masa Tubuh pada Laki-laki Usia Lanjut. Penelitian Gizi dan Makanan, Juni 2017, 40(1), 29-34.

Gadekar, T., Dudeja, P., Basu, I., Vashisht, S., \& Mukherji, S. (2020). Correlation of visceral body fat with waist-hip ratio, waist circumference and body mass index in healthy adults: A cross sectional study. Medical Journal Armed Force India, 2020, 76, 41-46.

Hall, J.E., do Carmo, J.M., da Silva, A.A., Wang, Z., Hall, M.E. (2015). Obesity-induced hypertension: Interaction of neurohumoral and renal mechanisms. Circ. Res. Pubmed. 116, 991-1006.

Janssen, I., Heymsfield, S.B., Allison, D.B., Kotler, D.P., \& Ross, R. (2002). Body Mass Index and Waist Circumference Independently Contribute to the Prediction of Nonabdominal, Abdominal Subcutaneous, and Visceral Fat. Am J Clin Nutr. 2002 Apr;75(4), 683-688. doi: 10.1093/ajen/75.4.683. PMID: 11916754.

Kementerian Kesehatan RI. (2018). Hasil Utama RISKESDAS 2018. Jakarta.

Kementerian Kesehatan RI. Klasifikasi Obesitas Setelah Pengukuran IMT.http://p2ptm.kemkes.go.id/infographicp2ptm/obesitas/klasifikasi-obesitas-setelahpengukuran-imt. Accessed on October 30, 2021.

Kurniawan, L.B., Bahrun, U., Hatta, M., \& Arif, M. (2018). Body Mass, Total Body Fat Percentage, and Visceral Fat Level Predict Insulin Resistance Better Than Waist Circumference and Body Mass Index in Healthy Young Male Adults in Indonesia. $J$. Clin. Med. 2018, 7(5): 96. doi:10.3390/jcm7050096.

Lee HW, Kim KJ, Jung KS, Chon YE, Huh JH, Park $\mathrm{KH}$, et al. (2017) The relationship between visceral obesity and hepatic steatosis measured by controlled attenuation parameter. PLOS ONE 12(10): e0187066. https://doi.org/10.1371/journal.pone.0187066). 
Low, S., Chin, M.C., \& Yap, M. (2009). Review on Epidemic of Obesity. Annals of the Academy of Medicine, Singapore 38(1), 57-65.

Pasanta, D., Htun, K.T., Pan, J., Tungjai, M., Kaewjaeng, S., Chancharunee, S., Tima, S., Kim, H.J., Kæwkhao, J., \& Kothan, S. (2021). Waist Circumference and BMI are Strongly Correlated with MRI-Derived Fat Compartments in Young Adults. Life 2021, 11, 643. https://doi.org/10.3390/life11070643.

Pradana, A. (2014). Hubungan antara Indeks Massa Tubuh (IMT) dengan Nilai Lemak Viseral (Studi Kasus pada Mahasiswa Kedokteran Undip). Jurnal Media Medika Muda.

Samuel, V.T. \& Shulman, G.I. (2012). Mechanism for Insulin Resistance: Common Threads and Missing Links. Cell 2012, 148, 852-865.

Susantini, P. (2021). Hubungan Indeks Masa Tubuh (IMT) dengan Persen Lemak Tubuh, dan Lemak Viscelar di Kota Semarang. Jurnal Gizi Unimus, 10(1), 51.

Sommer, I., Teufer, B., Szelag, M., NussbaumerStreit, B., Titscher, V., Klerings, I., \& Gartlehner, G. (2020). The Performance of Anthropometric Tools to Determine Obesity:
A Systematic Review and Meta-Analysis. Sci. Rep. 10, 12699.

Wang, J.J., Wang, H.J., Liu, J.S., \& Ma J. (2013). The Association Between Body Mass Index, Waist Circumference with Body Fat Percent, and Abdominal Fat Rate in Overweight and Obese Pupils. Zhonghua Yu Fang Yi Xue Za Zhi,47(7), 603-607.

Wei Ping JIA, Jun-Xi, Kun-San Xiang, Hui-Juan LU, LeiChen. (2003). Prediction of Abdominal Visceral Obesity From Body Mass Index, Waist Circumference and Waist-hip Ratio in Chinese Adults: Receiver Operating Characteristic Curves Analysis. Biomedical Land Environmental Sciences, 16, 206-211.

Yajnik, C.S. \& Yudkin, J.S. (2004). The Y-Y paradox. Lancet. 365:263.

Yasmeen, R., Reichert, B., Deiuliis, J., Yang, F., Lynch, A., Meyers, J., et al. (2013). Autocrine Function of Aldehyde Dehydrogenase 1 as a Determinant of Diet- and Sex-Specific Differences in Visceral Adiposity. Diabetes. 62(1),124-136. 